The Third Pole: Journal of Geography

Vol. 17: 37-50, 2017

Department of Geography Education, Central Department of Education, T.U., Kathmandu, Nepal

\title{
FOREST RESOURCE MANAGEMENT AND LIVELIHOOD OF LOCAL PEOPLE IN PANCHASE AREA OF WESTERN HILLY REGION, NEPAL
}

\author{
Devi Prasad Paudel ${ }^{1}$
}

\begin{abstract}
s
This paper attempts to explore the local people's perception of forest resources management and identify the contribution of forest resources for the livelihood of local people of Panchase area of western Nepal. Panchase area is very rich in biodiversity and natural beauty. A large part of the Panchase area is covered by forests and pasture land. The settlement of this area is situated in the middle of lower part of the Panchase hill. The study for the paper is based on both qualitative and quantitative methods. Both primary and secondary sources of information were used for this paper. Field observation, focus group discussion, key informant interview and informal discussion were conducted for exploring the local people's perception of resource management. A checklist was developed for key informant interview and informal discussion with local people in the study area. The relevant published and unpublished documents, books and journal were also reviewed as a secondary source of information for this paper. The paper is descriptive and qualitative in nature.
\end{abstract}

Keywords: Biodiversity, conservation, resource management, environment, ecological condition, livelihoods.

\section{Introduction}

Resource management is a common matter of concern of individual, community, society, governance system as well as internal and external forests (Poudel, 2012). It refers to any portion of the natural environment such as atmosphere, water, soil, forest, wildlife, land, minerals and environment assets (Pradhan and Pradhan,2006). Resource management

1 Dr. Paudel is an Associate Professor of Geography Education, Central Department of Education, T.U.Kirtipur,Email: devipaudel1@yahoo.com 
practices depend in the context. As the context changes, local people also search their culture and history for meaning that can be applied for managing the resources in the new context (Aase and Vetaas, 2007).

Sustainable livelihood approach was conceptualized in the work of Robert Chambers and Gordon Conway in the work entitled" Sustainable Rural Livelihood Practical Concepts for the $21^{\text {st }}$ Century" where they defined sustainable livelihood as follows:

A livelihood comprises the capabilities, assets (stores, resources, claims and access) and activities required for a means of living; a livelihood is sustainable which can cope with and recover from stress and shocks, maintain or enhance its capabilities and assets, and provide sustainable livelihood opportunities for the next generation; and which contributes net benefits to other livelihoods at the local and global levels and in short and long term(Chamber and Conway, 1992).

Livelihood strategies reflect the complexity of man environment relationship including local people's attempts to cope with environment utilizing available resources and adapting new options over time (Subedi and Pandey, 2002).

The livelihood strategies and livelihood outcomes are greatly dependent on the households assets as per livelihood framework includes five capitals namely human, physical, financial, social, and natural capitals (DFID, 2001). Forest resource is considered as a natural resources. The linkages between resources and livelihood have been recognized information on the availability and use of resources in terms of quantity and value in different socio-economic and ecological context. Forest resource in Nepal is closely linked to livelihoods of many people and their socio-economic development. Forest and people have reciprocal relationship for their mutual co-existence because a large number of people in developing countries live in and around the forests and depend on it for their life support. The forest resources for their daily livelihood for forest surrounding community through creation of financial capital (FAO, 2006). Although, forest itself is a natural capital, it has crucial role to create physical, social and financial capital which are prerequisites for basic livelihood.

The relationship between livelihood of the people and natural resources is a complex and interdependent phenomenon. In developing countries like Nepal, significant number of people living in subsistence agriculture and majority of them are still dependent on forest resources for their livelihood. 
Nepal is one of the richest countries in bio-diversity owing to its unique ecological condition and altitudinal variation. Biodiversity profile of Nepal 1996(BPN) greatly endeavored to document all the information available and recorded in the field of Nepal's bio-diversity. The profiles recorded 181 mammals'species, 884 birds' species 100 reptiles' species, 43 amphibian species 185 fresh water fish species, and more than 500 butterfly species. In the context of flora, BPN recorded 5160 species of flowering plants and 1120 non- flowering plants. According to BPN, Nepal ranks $10^{\text {th }}$ in terms of richness of flowering plant diversity in Asia and $31^{\text {st }}$ in the world (BPN, 1996; and CBD, 2000).

As elsewhere, land, forests, minerals and water remain the major natural resources in Nepal for human survival and livelihood. Rural population especially poor landless, indigenous people and women depend heavily on forest resources for their livelihoods (UNDP, 2016). Around 86 percent of total energy for cooking and 40 percent of fodder comes from forest (World Bank, 2006). Forest resources are necessary to preserve the ecology of the world that supports all of the natural resources and human life and livelihood.

Management of natural resources involves identifying who has the right to use the resource and who does not for defining the boundaries of the resource (Ostrom,1990 cited in Kommers and Mackie, 2005). The resources are managed by the users according to the rules and conditions governing when and how the resource is used.

The region has a great biological, cultural and religious diversity and natural beauty. Many Himalayas can be seen from this place. It represents an important middle mountain's ecological zone, which is less addressed amongst the country's protected area system and is only one corridor linkage of lowland.

This is the place where Sunakhari is found in about 113 different varieties. The region is famous for its diversity, featuring Laligurans, Kharsu, Chap Chandan and more than 600 varities of vegetation. The area is also popular territory for different animals such as tiger, bear, foxes and deer ( https//en. Wikipedia.org./wiki/ kaski district).

After the administrative restructuring the country into a federal model this area is now converted into Andhikhola, Phedikhola, Modi rural municipality and Pokhara Lekhanath metropolitan city. The whole part of the then existing VDCs are under the Panchse area but all part of above mentioned rural municipalities and metropolitan city are not included in the study area. 
The forest is sub-tropical and temperate mixed evergreen forest. The region is very rich in plant diversity. Red rhododendron of different species are the major blossoming plants. Out of 377 species of orchids (Sunakhari), 113species are available in Panchase area. Among them 3 species are endemic to Panchase. Now, this area is under the Panchase Protected Forest area (PPFA) comprises with 15964households and 62001 population, Kaski, Parbat and Syangja districts (IUCN, 2014).The lowest elevation lies in the valley of Seti and Modi River. The Panchase area is composed of hills and valleys of different elevation. Forest ecosystem is the dominants types of covering 61 percent of the land area

Until the late 1970s, the Government of Nepal (GoN) did not pay particular emphasis on the natural resource management in its development policies. It was only after the seventies that the GoN incorporated policies for the wise use of these resources in different policy documents.

During 1960s the term natural resources incorporated the biodiversity. In those days, protection of the resources was a common terminology used for both conservation and protection. In Nepal, concept of sustainable use of natural resources was first incorporated in periodic five-year plan in1980s. This plan highlighted the resource conservation through watershed management and land use control at the policy level (NPC, 1980).

The explicit concern for environment was expressed in the sixth plan(1980-1985), which stipulated a number of policy measures for conservation and sustainable use of natural resources.

In the beginning of 1990s the GoN formulated its separate environmental policy, for the protection and management of natural resources and its surroundings along with long term national plans focused on sustainable development and poverty alleviation.

In the context of Nepal, local people have identified different types of medicinal plants for a long time for curing the different types of diseases. Nepal's national economy and people's livelihood largely depend on natural resources. A large part of the study area in the region is covered by forests and pasture land. The settlements are situated on the middle of lower part of the Panchase hill. Panchase area is carrying the lots of possibilities such as water resources, tourism and religious places. However, this study is limited to the forest resources of this area. This paper has attempted to identify the importance of forest resources and to understand the local people's perception regarding the forest resources. 


\section{Methods and Material}

A large part of the Panchase area is covered by forests and pasture land. The settlement of this area is lying on the middle of lower part of the Panchase hill. This paper is based on both qualitative and quantitative methods.Both primary and secondary sources of information were used for this paper. Field observation, focus group discussion, key informant interview and informal discussion were conducted for exploring the local people's perception of resource management. A checklist was developed for key informant interview and informal discussion with local people in the study area. The relevant published and unpublished documents, books and journal were also used for secondary source of information. The paper is descriptive and qualitative in nature.

There are 17 settlements of the study area. Only six settlements( 35 percent) which are close to Panchase area were randomly selected for household survey. The nearest households from Panchase peak were selected on purpose. For this study, the selected settlements are more frequently dependent on forests resources near the Panchase area. Focus group discussion (FGDs), key informant interview (KII), field observation were also applied for collection of primary information. Altogether 176 households were selected for the interview. FGDs were conducted at six different places i.e. Bangsing Deurali, Bage Phadke, Chapakot, Arthar Dandakharka, Bhadaure Tamage and Bhatkhola. Minimum of 6 to 8 persons representing male and female from the different ethnic background and income level participated in the key informant interview. Different types of key persons such as old experience persons, school teachers, and members of community forest users group and other local organizations in the settlement were taken as key informants. The list of the sample size is shown in the table below.

Table 1: List of sample size of settlements

\begin{tabular}{lrrrr}
\hline Settlements & Total Households & Sample Households & KII & \multicolumn{2}{c}{ FGDs } \\
\hline Bangsing Deurali & 584 & 29 & 1 & 1 \\
Bange Phadke & 287 & 14 & - & 1 \\
Chapakot & 638 & 32 & 1 & 1 \\
Bhadaure Tamage & 762 & 38 & 1 & 1 \\
Bhatkhola & 471 & 24 & 1 & 1 \\
Arthar, Dandakharka & 775 & 39 & 1 & 1 \\
\hline Total & 3517 & 176 & 5 & 6 \\
\hline
\end{tabular}

Source: Field Survey, 2015 


\section{Study Area}

Panchase area is located $28^{\circ} 01^{\prime} 25^{\prime \prime}$ to $28^{\circ} 15^{\prime} 56^{\prime \prime}$ North latitude and $83^{\circ} 48^{\prime} 03^{\prime \prime}$ to $83^{\circ}$ 49' 53" East longitude, covers with 57.75 Sq.Km.Panchase Area. The highest peak of the Panchase is 2517 meters from the mean sea level. Now, this area has been declared as the conservation area by the GoN in 2068 BS. The settlement of BangsingDeurali, BangePhadke, Bhatkholaof Syangja district, BhadaureTamage, and Chapakot of Kaski district and Arthar-dandakharka of Parbat district wereincluded in the study area. Panchase conservation area is located at Mahabharat range, among the three districts i.e. Syangja, Kaski, and Parbat. This area is very much rich in biodiversity and natural beauty. The total population of this study area is only 20,182 with 3517 households.

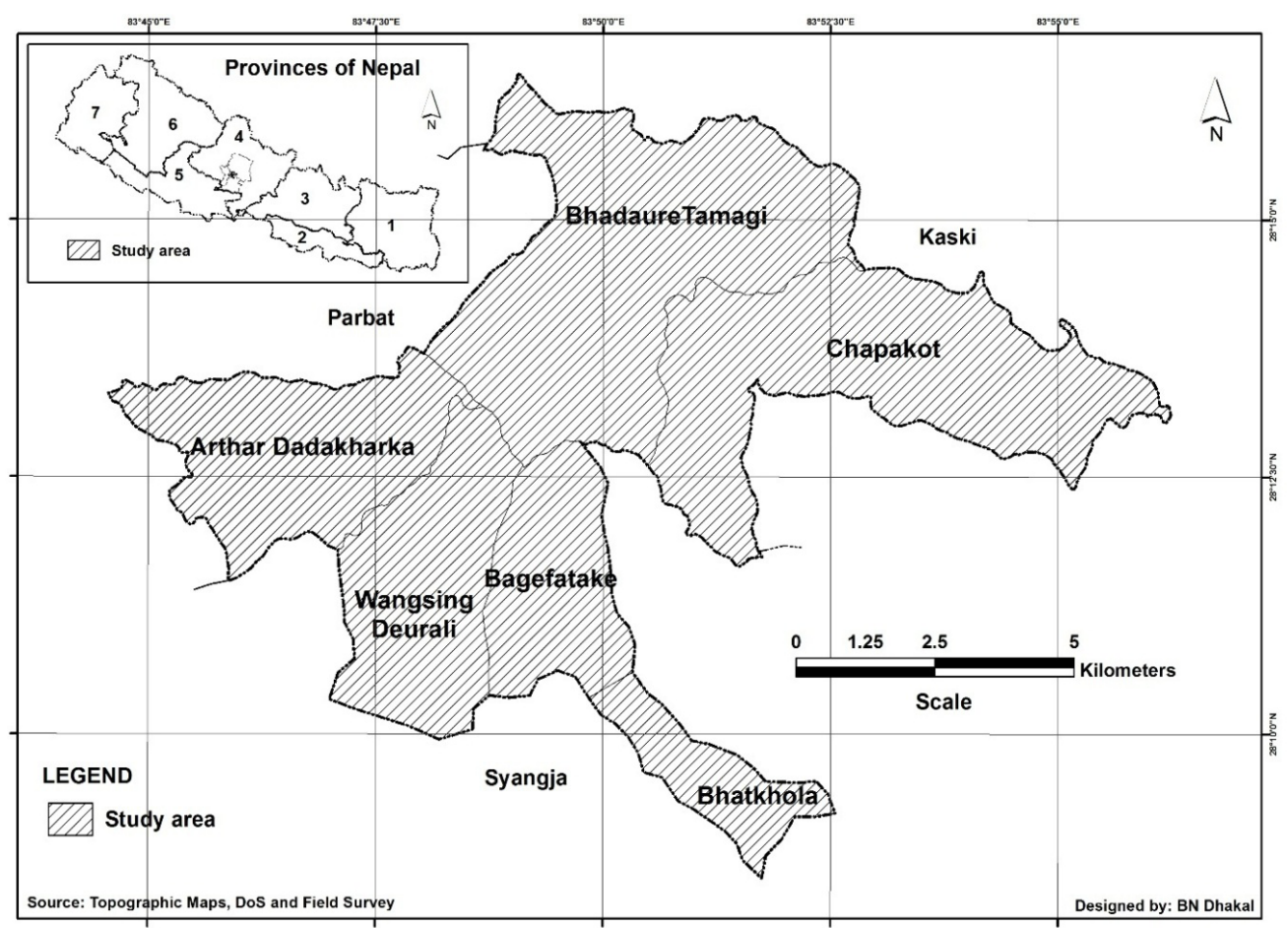

Figure 1: Location map of study area

The study area, Panchase Lake forms the Tri-junction of Kaski, Syangja and Parbart districts. It is nearly equidistance from the Headquarter of the districts, located at Pokhara, Putalibazar and Kusma town respectively. Panchase Lake is also considered a sacred place especially for the people of Hindu and Buddhist community. Panchase literally meaning Pancha: five: Asan: Seats, in the meeting place of 5 peaks roofed with lush green forest with diverse flora and fauna. Panchase area lies in the settlements of 
Devi Prasad Paudel / Forest Resource Management and Livelihood of Local People ...

Kaski, Parbat and Syangja district of western development region, which starts from 1450 meters to 2557 meters. Panchase is a national forest designated as protected under Forest Act-1993, in the year 2011, is managed and governed by the government (Kunwar and Upadhaya, 2012).

\section{Result and Discussion}

\section{Biodiversity}

There are different types of species of vegetation available like Chiraito, Sugandhabal, Bajradanti, Nagbeli and Lokata including 107 species of Jadibuti (herbs), 56 species of mushroom, 98 species of unio, 113 species of Sunakhari (orchid)out of 377 types of orchid species found in Nepal and 7species of Laligurans (rhododendron) are found in this area Sunakhari is popular as the local export of this area and is taken as the asset of the area. There are two types of peculiar orchid in this area, which are not found in other area in the world i.e. paniseapanchanensis and Eriapakhrerensis. So, this is considered the indigenous species of this area. About 35 species of orchid of this area out of 113 are used for medicinal purpose.

This area is also the shelter of different types of wildlife and birds. Leopard, beer, jackle forest cat, monkey etc. Dhukur, Koili, Kalij, Lampuchhre, Crow, Bakulla etc. Despite the area being full of biodiversity, very efforts have been made for the conservation and utilization of very expensive herbs in this area.

Some local people doing hotel and homestay have, for the majority of the season, used local products such as bamboo shoot, Kaliniuro, Kurilo, Jaluka as vegetables and dhido (made from the flour of millet and buckwheat), and Aato (made from maize) as food. Local wine (made from millet) and local goats and chicken have been made available locally for the guests of the hotel and homestay. This has attracted many domestic tourists as well in the area. Some hotels are running in Bhanjyang, the nearest settlement of Panchase lake. One hotel is located on top of Panchase itself. Homestay is mostly popular in Bhadaure Tamage and Arthar Dandakharka where the clustered settlements of Gurung community have added beauty to the diversity. These types of economic activities are, on most part, based on forest product for some local people livelihood.

\section{Local People's Perception of Forest Resources}

According to local people, Panchase area is very important for them as they find different types of medicinal and aromatic plants widely used for local medicine. Ourancestors have shared the idea of use of medicine, if we preserve these medicinal herbs properly we can develop rich biodiversity and improve the livelihood', said one local resident. 'Still now, very expensive herbal plants are found to cure the complex diseases like 
cancer, but authorities seem not to be serious to take step to preserve these treasures' he further said. As we know there are some important medicinal plants which were found to have used by the local people for the treatment and for their livelihood.

Table 2: List of medicinal plants with their ethnological used found in Panchase area

\begin{tabular}{|c|c|c|c|}
\hline Botanical name & Local name & Parts used & Ethno-medicinal uses \\
\hline $\begin{array}{l}\text { P. Polyphylla- } \\
\text { (Liliaceae) }\end{array}$ & Satuwa & Rhizomes & $\begin{array}{l}\text { Roots paste is applied to wounds for } \\
\text { rapid healing and bite for poisonous } \\
\text { insects and snake bite. }\end{array}$ \\
\hline $\begin{array}{l}\text { Swertia Chiraito } \\
\text { Gentianaceae }\end{array}$ & Chiraito & $\begin{array}{l}\text { Whole } \\
\text { plants }\end{array}$ & $\begin{array}{l}\text { Juice of plant boiled water is used to } \\
\text { get relief from fever, stomach paining, } \\
\text { typhoid high blood pressure diabetes } \\
\text { and joint problem. }\end{array}$ \\
\hline $\begin{array}{l}\text { Asparagus } \\
\text { Vacemousus } \\
\text { (Liliaceae) }\end{array}$ & Kurilo & $\begin{array}{l}\text { Tender } \\
\text { shoots } \\
\text { Root }\end{array}$ & $\begin{array}{l}\text { Root paste is used to treat fever and as a } \\
\text { tonic to lactating women and livestock. }\end{array}$ \\
\hline $\begin{array}{l}\text { Linderaneesiana } \\
\text { (Liliaceae) }\end{array}$ & Siltimur & Seed & $\begin{array}{l}\text { Seeds are used in treating stomach } \\
\text { paining and diarrhea. }\end{array}$ \\
\hline $\begin{array}{l}\text { Acoruscalamus } \\
\text { (Araceae) }\end{array}$ & Bhojo & Rhizomes & $\begin{array}{l}\text { Rhizomes are used to treat cough, cold } \\
\text { throat infection and diarrhea. }\end{array}$ \\
\hline $\begin{array}{l}\text { Urticadioca } \\
\text { (Urticaceae) }\end{array}$ & Sisnu & $\begin{array}{l}\text { Roots, } \\
\text { tender } \\
\text { shoots }\end{array}$ & $\begin{array}{l}\text { Tender shoots are used as vegetable. } \\
\text { Roots juice is used for cooling purpose. }\end{array}$ \\
\hline $\begin{array}{l}\text { Tinospora Sinensis } \\
\text { (merispermaceae) }\end{array}$ & Gurjo & $\begin{array}{l}\text { Whole } \\
\text { plants }\end{array}$ & $\begin{array}{l}\text { Plant is used for urinary problem. } \\
\text { Roots juice is used to treat diarrhea and } \\
\text { dysentery. }\end{array}$ \\
\hline $\begin{array}{l}\text { Combrutum } \\
\text { Roxburghii } \\
\text { (Combretaceae) }\end{array}$ & Thakailo & Roots & $\begin{array}{l}\text { Root juice is used to treat fever and } \\
\text { cooling purpose. }\end{array}$ \\
\hline $\begin{array}{l}\text { Artenisia Volgaris } \\
\text { (Compositae) }\end{array}$ & Titepati & Leaves & Leave paste is used in wound. \\
\hline $\begin{array}{l}\text { Arisaemaintermedium } \\
\text { (Araceae) }\end{array}$ & $\begin{array}{l}\text { Sarpako } \\
\text { Makai }\end{array}$ & $\begin{array}{l}\text { Roots, } \\
\text { leaves }\end{array}$ & Roots paste is applied in case of ulcer. \\
\hline Classampelispareira & Gujargano & $\begin{array}{l}\text { Whole } \\
\text { plant }\end{array}$ & $\begin{array}{l}\text { Roots are used for coughing diarrhea, } \\
\text { snake bite etc. }\end{array}$ \\
\hline $\begin{array}{l}\text { Centella, Siatia } \\
\text { (Umbrelliferae) }\end{array}$ & Gholtapre & Leaves & $\begin{array}{l}\text { Plant is used for treatment of skin } \\
\text { diseases and cooling purpose. Leave is } \\
\text { used for headache. }\end{array}$ \\
\hline Imperata cylindrical & Siru & Roots & Roots paste is used as an ant parasite. \\
\hline $\begin{array}{l}\text { Berginia ciliate } \\
\text { (Saxifragaceae) }\end{array}$ & Pakhanbed & Rhizomes & $\begin{array}{l}\text { Juice from rhizomes is useful in joint } \\
\text { problem. }\end{array}$ \\
\hline
\end{tabular}

Source: Field Survey, 2015 
Table 2 shows different types of medicinal plants, which were identified by the local people since time immemorial. According to local participants there are still so many medicinal plants which has not been identified yet, can be used as medicine.

\section{Livelihood Strategy of Local People}

The local people of this area is basically depends on forest products, agriculture and livestock for their livelihood. Some economic activities of local people based on following discussion.

\section{Status of Livestock for the Livelihood of Local People}

Livestock is considered as a non-land asset in rural area of Nepal. It can be considered as an integral part of the agricultural economy in the context of Nepal. Most of the people of Panchaseand adjoining areas are engaged in agriculture and livestock for their livelihood (Field Survey, 2015).

Since long time, the people of thisarea are living in Kharkawith theirlivestock. The livestock farming in Kharka is an indigenous practice of local people. Now, this type of practice is disappearingdue to lack of protection and increasing encroachment of forest. But some people have been doing such practice in many places (Field Survey, 2015). Welfare of the rural people depends on number of livestock population along with crop production. Livestock are raised by local people for meat and milk production and consumption as well as selling and making dairy products. The status of livestock in the study area is as follows.

\section{Table 3: Number of Major livestock}

\begin{tabular}{lrr}
\hline Types of livestock & Number of livestock & Percentage \\
\hline Buffaloes & 352 & 13.68 \\
Cow/Oxen & 164 & 6.37 \\
Goat/Sheep & 632 & 24.57 \\
Chicken/ducks & 1246 & 48.44 \\
Pigs & 178 & 6.92 \\
\hline Total & 2572 & 100.00 \\
\hline
\end{tabular}

Sources: Field Survey, 2015 
Each and every households of the rural area have livestock such as buffalo, cow, goat, chicken ducks etc. with domination of chicken more than 48 percent of the sample households. Number of goats is in more than 24 percent, sheep population seems to have disappeared in the rural settlements. The number of buffaloes are more in compared to cow and oxen because of large part of agriculture land is difficult terrain and not good for farming. So, oxen are not needed to plough the field. Poultry farming is getting increased day by day in large number in the villages. Pigs are also considered important to improve the livelihood of poor people of the villages of this area. Fodder collection for the farmed buffaloes, goat and cow has become difficult because of the scarcity of labor in the rural areas.

\section{Forest Resources and Livelihood}

Forest is one of the most important natural resources in which people directly or indirectly depend for their livelihood, particularly, in the rural communities in Nepal. The rural people have largely been dependent on forest from ancient time for firewood, timber, grass, agricultural tools and other domestic needs as well as medicinal herbs available from non-timber forest products (NTFPs). All those forest products are an integral part of rural livelihood. The livestock is a part of rural livelihood and it is mostly dependent on forest as it provides fodder and grazing space to the livestock. So, forest can be considered as one of the most important natural resources for rural people's livelihood. Forest and people's livelihood are interrelated in terms of forest resources use especially in rural area in developing countries like Nepal. Most of the local people use firewood for cooking food and for making Kundho (cooked grain food for buffalo and cow). The average firewood use per households a day is 1Bhari (Bhari is a kind of head or back load). Fuel wood is collected for selling purpose as well. The hotel areas in local bazar are the major place for selling wood by the local people for their livelihood. Medicinal plants like Satuwa, Chiraito, timbur etc. is sold in Pokhara bazar that has the special knowledge of that area. Bamboo shoot, Kali Niuro, Kurilo etc. are also sold in Pokhara. Seasonal fruits like Chutro, Kaphal Aeiselu Naspati, Aaru, Khurpane etc. are available especially in Shidhane, Bangsing, Saradi, Arthar, Kaule, Bhanjyang, Karamdi village of the study area. But, fruit selling is not in large scale. Now, some community forest user groups are trying to produce the fruits in commercial scale. These are the major forest resources to the local people for their livelihood. Some local people in the study area say 'if we have transportation facility to reach easily in market, it will increase production in large scale'. The following table shows the utilization status of forest products in the study area. 
Devi Prasad Paudel / Forest Resource Management and Livelihood of Local People ...

Table 4: Utilization of forest products in monetary value

\begin{tabular}{lrrr}
\hline Types & $\begin{array}{l}\text { Quantity Bhari/per } \\
\text { Households/year }\end{array}$ & $\begin{array}{l}\text { Monetary Value } \\
(\mathrm{NRs})\end{array}$ & Percentage \\
\hline Fuel wood & 16250 & 5862 & 10.30 \\
Timber (Per/Cu. Ft.) & 322 & 322 & 0.56 \\
Fodder & 4200 & 9036 & 15.88 \\
Fruits & 4620 & 6305 & 11.08 \\
Medicinal plants & 3.6 & 32113 & 56.44 \\
Others & - & 3254 & 5.71 \\
\hline Total & & 56892 & 100.00 \\
\hline
\end{tabular}

Source: Field Survey, 2015

Note: 1Bhari is equivalent to $50 \mathrm{~kg}$.

Table 4 shows that the forest products utilization by the local people both in quantity and monetary value. Of the total utilization of forest, nearly 57 percent is from medicinal plants, followed by 16 percent from fodder and 11 percent fruits in the study area. Fuel wood comprises only 10 percent in terms of monetary value through the quantity of fuel wood consumption is high as compared to other products from the forest resources. Some products such as leaf litter and bedding materials of animals are distributed free of cost to the users. However, the field survey revealed that the pricing of forest products and its distribution system are not well managed in the study area. Medicinal herbs prices and distribution system depends on special community and members of community forest user group's decisions because of its irregular products in the study area.

\section{Practice of Natural Resources Management}

Panchase area is the main watershed area of Phewa Lake. In the last few years decomposition of soil in Phewa Lake is increasing day by day. So, different types of forest conservation programs help to control soil erosion in the watershed area. The open grazing was controlled and encroachment was also prevented. Local people planted fodder and forest trees along their open land, homeland and other utilized places, thus reducing the barren land. Landslide, soil erosion construction of unplanned rural transportation and loss of water spring are increasing due to the depletion of forests. The local communities have carried out training to develop skilled human resources with the support of INGOs and NGOs, who can manage NTFPs at the local level. Farmers have started seasonal and off-seasonal vegetation farming, bee keeping, and coffee farming. 
These activities have generated additional income for the people. Locally, available resources- natural, human and financial resources have been well mobilized and utilized. The forest conservation and well management has eased their lives in collecting fodders and fuel wood. The program has also provided them resources for developing micro enterprises. Now, the Panchase area has been changed into greenery area.

\section{Conclusions}

The present paper concludes that Panchase area is very rich in biodiversity representing the healthy ecosystem. However, the forest resources management mechanism is weak, the forests are being degraded due to open livestock grazing and unsustainable harvesting the forest products in some places. The local community forests user groups of this area have supported to protect the forests for their livelihood. However, CFUFs members seem not to be careful to conserve the biodiversity due to their special plant species plantation and silviculture programs. Due to the afforestation program in this area, the local people were found happy that the conservation of natural resources was managed properly.

The collection of medicinal herbs is not scientific and development of expensive herbal was not possible due to lack of resources. Low participation of local people in the conservation of natural resource has been another challenge. The government was not officially involved to the conservation of natural resource of the study area.

Due to overgrazing and transhumance system of livestock, loss of biodiversity is the major problem of environmental conservation of this area. Traditional Kharka (transhumance) system of livestock should be managed properly. The construction of rural transportation should be managed on the basis of Environmental Impact Assessment (EIA) or it should be made environment friendly.

Being rich in biodiversity, this area should be conserved, developed and managed properly from the government sector and local community. The area should be promoted as herbal farming to the local people or community and provide technical training to that community.

Special trekking route should be made for conservation of natural beauty and environment. Level of awareness among the users should be increased so as to promote local level 
Devi Prasad Paudel / Forest Resource Management and Livelihood of Local People ...

initiatives for the conservation of the forest and biodiversity, which ultimately would contribute to local people's livelihood.

\section{References}

Aase, T.H., and Veetaas, O.R. (2007). Risk management by communal decision in transHimalayan farming: Manang Valley in central Nepal Human Ecology, 35:453460.

Convention on Biological Diversity(CBD).(2000). Global strategy on invasive alien species. Kathmandu: CBD/UNEP.

Central Bureau of Statics (CBS).(2011). Population monograph of Nepal. Kathmandu: CBS.

Chambers, R and Conway (1992).Sustainable rural livelihoods: practical concepts for the $21^{\text {st }}$ century. Discussion Paper 240. Institute of Development Studies.

DFID. (2001).Sustainable livelihood guidance sheets. The Department for International Development of the United Kingdom.

DoF. (2015). www.dof. Gov.np. website of the department of forest, Government of Nepal.

DDC. (2015). A handbook of district development committee, Pokhara: DDC Kaski.

FAO. (2006).Better forestry, less poverty: Apractioner's guide. Rome: FAO.

Kunwar, B.B. and Upadhayaya, M. (2013). Orchid of Panchase. Pokhara: Department of Forestry.

NBP. (1996). Nepal biodiversity resource books.Icimod.urg./index.php/download/ Publication/183).

NPC. (1992). Eight five year plan, Kathmandu: National Planning Commission, GoN.

NPC. (1980). Sixth five year plan. Kathmandu: National Planning Commission, GoN.

Kommers, N and Mackie,P.(2005). Journalist guide to world resources 2005, World Resource Institute1-30.

Pradhan, P.K. and Pradhan, B. (2006). Environment and natural resources: Concept, methods, planning and management. Kathmandu: Quest Publication. 
The Third Pole: Journal of Geography, Volume 17, 2017

Poudel, K. P. (2012). Fundamental of resource management, principles and practices Saarbrucken, Germany: LAP LAMBERT Academic Publishing GmbH and Co. $\mathrm{K}$.

Subedi, B.P. and Pandey, R. (2002).Livelihood Strategies of Rai Community in Arun Valley: Continuity and Change, Vegetation and Society: Their interaction in the Himalyan, Tribhuvan University, Nepal and University of Bergen, Norway.

UNDP/IUCN(2016).Ecosystem based adaptation in mountain ecosystem in Nepal (EBA) Unpublished reports. UNDP and Department of Forests. 